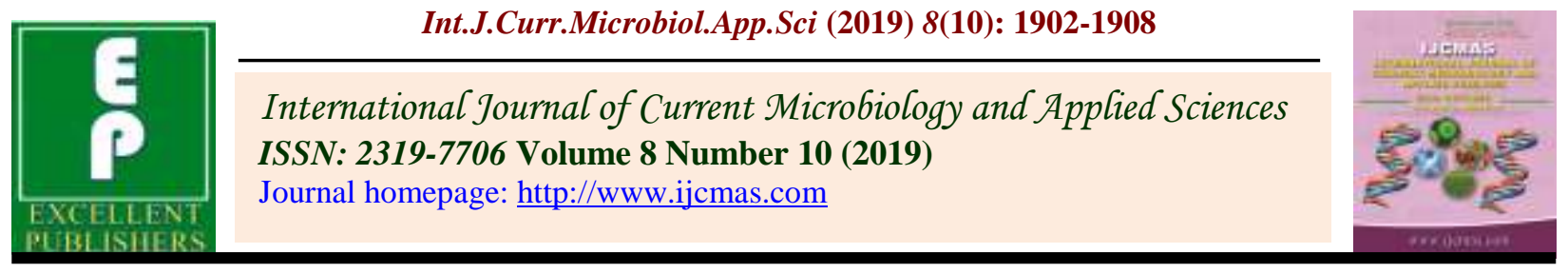

Original Research Article

https://doi.org/10.20546/ijcmas.2019.810.221

\title{
To Workout the Economics and Energetics of Lentil as Influenced by Irrigation and Foliar Spray of Nutrients and Growth Hormones
}

\author{
D.K. Chandrakar, Bharti Sodi and Tarun* \\ Department of Agronomy, College of Agriculture, IGKV, Raipur-492012, Chhattisgarh, India \\ *Corresponding author
}

\section{Keywords \\ Lentil, Irrigation, Growth hormones, Nutrient uptake, Water use efficiency}

\section{Article Info}

Accepted:

15 September 2019

Available Online:

10 October 2019

\section{A B S T R A C T}

The field experiment was conducted during rabi season of 2017-18 at the Instructional Cum Research Farm, under all India Coordinated Research Project on MULLaRP, Department of Agronomy, College of Agriculture, I.G.K.V. Raipur (CG.) The use of growth regulators is becoming popular to enhance crop productivity and varieties of such substances are available in the markets which are being utilized for crop production. Foliar application should be timed to provide needed nutrients during the yield determining growth stages. Plant growth regulators are the chemicals which influence the plant growth when applied in very minute quantity. The experiment was laid out in Strip Plot Design having the combination of fourteen treatments and three replications. The treatment consisted of seven foliar nutrients spray and two irrigation levels. The experiment was comprised of factor A. Horizontal plot (Irrigation level-2) $\mathrm{I}_{1}$-One irrigation (35 DAS), $\mathrm{I}_{2}$ Two irrigation (35 and 65 DAS) B. Vertical plot (Foliar Spray-7) $\mathrm{F}_{1}$-Water Spray, $\mathrm{F}_{2}$ Nitrobenzene @ 0.3\%, $\mathrm{F}_{3}-\mathrm{N}: \mathrm{P}: \mathrm{K}::$ 19:19:19 @ 1\% solution, $\mathrm{F}_{4}$-Multi micro nutrient (Fe, $\mathrm{Mn}, \mathrm{Zn}, \mathrm{B}, \mathrm{Cu}, \mathrm{Mo}$ ) @ 0.1\%, F 5 -Plant growth hormones mixture (Cytokinins and Enzymes) @ 0.15\%, F-N: P: K:: 19:19:19:@ 1\% + Multi micro nutrient (Fe, Mn, Zn, B, $\mathrm{Cu}, \mathrm{Mo}) @ 0.1 \%, \mathrm{~F}_{7}-\mathrm{N}: \mathrm{P}: \mathrm{K}::$ 19:19:19 + Multi micro nutrients + Plant growth hormones. Significantly maximum N, P and K uptake in seed, stover as well as in total was recorded with $\mathrm{I}_{2}$-Two irrigations followed by $\mathrm{I}_{1}$-One irrigation. As regards to foliar spray, significantly higher $\mathrm{N}, \mathrm{P}$ and $\mathrm{K}$ uptake in seed, stover and in total was noted under $\mathrm{F}_{7}-\mathrm{N}$ : $\mathrm{P}$ : K:: 19:19:19 + MMN + PGHM as compared to others, however, it was at par to

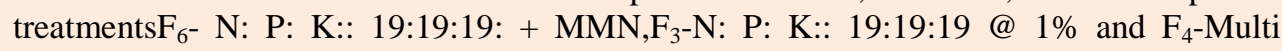
Micro Nutrients. Between the irrigation levels, significantly higher water use efficiency $\left(86.79 \mathrm{~kg} \mathrm{ha}^{-1} \mathrm{~cm}\right)$ was recorded with $\mathrm{I}_{1}$-One irrigation as compared to $\mathrm{I}_{2}$-Two irrigation $\left(66.06 \mathrm{~kg} \mathrm{ha}^{-1} \mathrm{~cm}\right)$. As regards to the foliar spray of micronutrients and growth hormones, maximum water use efficiency $\left(89.56 \mathrm{~kg} \mathrm{ha}^{-1} \mathrm{~cm}\right)$ was recorded with $\mathrm{F}_{7}-\mathrm{N}: \mathrm{P}: \mathrm{K}::$ 19:19:19 + MMN + PGHM. However, it was at par to treatment F $-\mathrm{N}: \mathrm{P}: \mathrm{K}::$ 19:19:19 + MMN $\left(82.13 \mathrm{~kg} \mathrm{ha}^{-1}\right)$. The minimum water use efficiency $\left(58.03 \mathrm{~kg} \mathrm{ha}^{-1} \mathrm{~cm}\right)$ was observed with $\mathrm{F}_{1}$ - Control (water spray). 


\section{Introduction}

In India, it is grown over an area of $1.27 \mathrm{~m}$ ha with an annual production of $0.976 \mathrm{mt}$ and an average productivity of $765 \mathrm{~kg} \mathrm{ha}{ }^{-1}$ (Anonymous, 2016-17). Lentil varieties developing larger and deeper root system are advantageous for sustaining yield in nutrientpoor soils of dry areas. Nutrient uptake by crop plants is generally decreased under water-stress conditions owing to a substantial decrease in transpiration rates and impaired active transport and membrane permeability and resulting in a reduced root-absorbing power of crop plants. So there is much need to give fertilizers through soil as well foliar application. Like fertilizer, micronutrient, growth regulators are also important. Low and variable seed yield is a major problem limiting the production and rapid expansion of grain legumes including lentil in tropic. The serious problem of flower drop and poor seed setting need serious attentions. Some micronutrients and growth substances are being increasingly employed as an aid to enhance yield. Micronutrients viz., zinc boron, iron, manganese, copper, molybdenum and growth substances were found to successful as a foliar spray in some crops to overcome deficiency of particular micronutrient, increasing photosynthetic efficiency, prevent senescence.

The use of growth regulators is becoming popular to enhance crop productivity and varieties of such substances are available in the markets which are being utilized for crop production. Foliar application should be timed to provide needed nutrients during the yield determining growth stages. Plant growth regulators are the chemicals which influence the plant growth when applied in very minute quantity. There are many reports which indicate that application of growth regulators enhanced plant growth and crop yield (Ashraf et al., 1989 and Hernandez, 1997).

\section{Materials and Methods}

The field experiment was conducted during rabi season of 2017-18 at Instructional cum Research Farm, I.G.K.V. Raipur, Chhattisgarh comprised of horizontal and vertical factor against effect of irrigation and foliar spray of nutrients and growth hormones on growth, yield attributes and yield of lentil. The treatment consisted of seven foliar nutrients spray and two irrigation levels. The experiment was laid out in Strip Plot Design having the combination of fourteen treatments and three replications. The experiment was comprised of factor A. Horizontal plot Irrigation level-2 $\mathrm{I}_{1}$-One irrigation (35 DAS) $\mathrm{I}_{2}$-Two irrigation (35 and 65 DAS) factor $\mathrm{B}$. Vertical plot Foliar Spray-7 $\mathrm{F}_{1}$-Water Spray $\mathrm{F}_{2}$-Nitrobenzene @ $0.3 \% \quad \mathrm{~F}_{3}-\mathrm{N}: \quad \mathrm{P}: \mathrm{K}::$ 19:19:19@1\% solution $\mathrm{F}_{4}$-Multi Micro Nutrient (Fe, Mn, Zn, B, Cu, Mo) @0.1\% F FPlant growth hormones mixture (Cytokinins and Enzymes) @ $0.15 \% \quad \mathrm{~F}_{6}-\mathrm{N}: \quad \mathrm{P}: \quad \mathrm{K}::$ 19:19:19:@1\% + Multi Micro Nutrient (Fe, $\mathrm{Mn}, \mathrm{Zn}, \mathrm{B}, \mathrm{Cu}, \mathrm{Mo}) @ 0.1 \% \mathrm{~F}_{7}-\mathrm{N}: \mathrm{P}: \mathrm{K}::$ 19:19:19 + Multi micro nutrients + Plant growth hormones. The soil of the experimental field was Vertisols with low, medium and high in $\mathrm{N}, \mathrm{P}$ and $\mathrm{K}$, respectively and neutral in reaction. The climate of the region is sub-humid to semi-arid.

\section{Results and Discussion}

\section{Economics}

\section{Gross return (Rs. ha $\left.{ }^{-1}\right)$}

Economics of lentil production in terms of gross return was calculated for different irrigation levels and foliar spray of micronutrients and growth hormones and data are presented in Table 1, 2, 3 and 4.

The data reveals that significantly maximum gross return (Rs. 48922.9 ha $^{-1}$ ) was received 
under $\mathrm{I}_{2}$-Two irrigations (35 and 65 DAS). Whereas, the minimum gross return (Rs. $42731.5 \mathrm{ha}^{-1}$ ) was received under $\mathrm{I}_{1}$-One irrigation (35 DAS).

Concerning to foliar spray of micronutrients and growth hormones, treatment $\mathrm{F}_{7}-\mathrm{N}$ : P: K:: 19:19:19 + MMN + PGHM received significantly maximum gross return (Rs. $54942.2 \mathrm{ha}^{-1}$ ). However, the minimum value of gross return (Rs.35627.0 ha-1 ) was noted under F1- Control (water spray).

The gross return of lentil due to interaction effect of irrigation levels and foliar spray of micronutrients and growth hormones was found non- significant.

\section{Net returns (Rs. ha $\left.{ }^{-1}\right)$}

Economics of lentil production in terms of net return was calculated for different irrigation levels and foliar spray of micronutrients and growth hormones and data are presented in Table 1. The data reveals that significantly maximum net return (Rs.30060.5 ha ${ }^{-1}$ ) was received under $\mathrm{I}_{2}$-Two irrigations (35 and 65 DAS) and minimum net return (Rs.24369.1 $\mathrm{ha}^{-1}$ ) was received under $\mathrm{I}_{1}$-One irrigation (35 DAS).

Concerning to foliar spray of micronutrients and growth hormones, treatment $\mathrm{F}_{7}-\mathrm{N}$ : $\mathrm{P}: \mathrm{K}:$ : $19: 19: 19+\mathrm{MMN}+\mathrm{PGHM}$ received significantly maximum net return (Rs. $33638.2 \mathrm{ha}^{-1}$ ). However, it was at par to treatments $\mathrm{F}_{3}-\mathrm{N}: \mathrm{P}: \mathrm{K}::$ 19:19:19 @ 1\% (Rs. 29968.6 ha $\left.{ }^{-1}\right), \mathrm{F}_{6}-\mathrm{N}: \mathrm{P}: \mathrm{K}::$ 19:19:19 + MMN (Rs 29863.1 $\mathrm{ha}^{-1}$ ) and F4-Multi micro nutrients (Rs. $28216.6 \mathrm{ha}^{-1}$ ). The minimum value of net return was noted under F1Control (water spray).

The net return of lentil due to interaction effect of irrigation levels and foliar spray of micronutrients and growth hormones was found non- significant.

\section{Return $\operatorname{Re}^{-1}$ invested}

Return $\mathrm{Re}^{-1}$ invested was calculated for different irrigation levels and foliar spray of micronutrients and growth hormones and data are presented in Table 1.

The data reveals that the irrigation levels failed to give significant impact on return $\mathrm{Re}^{-1}$ invested, however maximum value (2.59) was noted under $\mathrm{I}_{2}$-Two irrigations (35 and 65 DAS). The minimum return $\mathrm{Re}^{-1}$ invested (2.32) was received under $\mathrm{I}_{1}$-One irrigation (35 DAS).

As regards to foliar spray of micronutrients and growth hormones, treatment $\mathrm{F}_{7}-\mathrm{N}$ : $\mathrm{P}: \mathrm{K}:$ : $19: 19: 19+\mathrm{MMN}+\mathrm{PGHM}$ received significantly highest return $\mathrm{Re}^{-1}$ invested (2.65), but it was at par to rest of the treatments except treatment $\mathrm{F}_{1}$ - water spray (2.09).

The interaction effect of irrigation levels and foliar spray of micronutrients and growth hormones was found non- significant.

Sitaram et al., (2013) and Kumar et al., (2017) also noted that foliar spray of nutrients and growth hormones significantly increased the net returns and $\mathrm{B}$ : $\mathrm{C}$ ratio.

\section{Energetics}

\section{Energy output: input ratio}

Data calculated on energy output: input ratio of lentil at harvest has been presented in Table 5. Data shows that energy output: input ratio did vary due to irrigation levels.

However, in case of foliar spray of micronutrients and growth hormones, treatment $\mathrm{F}_{7}-\mathrm{N}: \mathrm{P}: \mathrm{K}::$ 19:19:19 + $\mathrm{MMN}+$ PGHM recorded significantly maximum energy output: input ratio (2.22). 
Table.1 Economics of lentil as affected by irrigation levels and foliar spray of micronutrients and growth hormones

\begin{tabular}{|c|c|c|c|c|c|}
\hline \multicolumn{2}{|c|}{ Treatment } & $\begin{array}{c}\text { Cost of } \\
\text { cultivation } \\
\left(\operatorname{Rs~ha}^{-1}\right)\end{array}$ & $\begin{array}{c}\text { Gross } \\
\text { return } \\
\left(\text { Rs ha }^{-1}\right)\end{array}$ & $\begin{array}{c}\text { Net } \\
\text { return } \\
\left(\text { Rs ha }^{-1}\right)\end{array}$ & $\begin{array}{c}\text { Return } \\
\mathbf{R e}^{-1} \\
\text { invested }\end{array}$ \\
\hline \multicolumn{6}{|c|}{ Irrigation levels } \\
\hline $\mathbf{I}_{1^{-}}$ & One irrigation (35 DAS) & 18362.4 & 42731.5 & 24369.1 & 2.32 \\
\hline $\mathbf{I}_{2^{-}}$ & $\begin{array}{l}\text { Two irrigations } \\
\text { (35 and } 65 \text { DAS) }\end{array}$ & 18862.4 & 48922.9 & 30060.5 & 2.59 \\
\hline \multicolumn{2}{|c|}{ SEm \pm} & & 894.4 & 894.4 & 0.05 \\
\hline CD & $P=0.05)$ & & 5442.3 & 5442.3 & NS \\
\hline \multicolumn{6}{|c|}{ Foliar spray } \\
\hline $\mathbf{F}_{\mathbf{1}^{-}}$ & Water Spray & 17038.0 & 35627.0 & 18589.0 & 2.09 \\
\hline $\mathbf{F}_{2^{-}}$ & Nitrobenzene @0.3\% & 18658.0 & 43425.0 & 24767.0 & 2.33 \\
\hline $\mathbf{F}_{3^{-}}$ & N:P: K:: 19:19:19 @ 1\% & 18163.0 & 48131.6 & 29968.6 & 2.63 \\
\hline $\mathbf{F}_{4^{-}}$ & $\begin{array}{l}\text { Multi Micro Nutrients } \\
(\mathrm{MMN})\end{array}$ & 18168.0 & 46384.6 & 28216.6 & 2.55 \\
\hline $\mathbf{F}_{5^{-}}$ & $\begin{array}{l}\text { Plant Growth Hormones } \\
\text { Mixture (PGHM) @ } 0.15 \%\end{array}$ & 18356.0 & 43817.1 & 25461.1 & 2.39 \\
\hline $\mathbf{F}_{\mathbf{6}^{-}}$ & N: P: K:: 19:19:19: + MMN & 19293.0 & 49156.1 & 29863.1 & 2.55 \\
\hline $\mathbf{F}_{7^{-}}$ & $\begin{array}{l}\text { N: P: K:: 19:19:19 + MMN } \\
\text { + PGHM }\end{array}$ & 20611.0 & 54249.2 & 33638.2 & 2.65 \\
\hline \multicolumn{2}{|c|}{ SEm \pm} & & 1893.6 & 1893.6 & 0.10 \\
\hline \multicolumn{2}{|c|}{$\mathrm{CD}(\mathrm{P}=\mathbf{0 . 0 5})$} & & 2834.8 & 5834.8 & 0.32 \\
\hline \multicolumn{2}{|c|}{ Interaction $\mathbf{I} \times \mathbf{F}$} & & NS & NS & NS \\
\hline
\end{tabular}

Table.2 Interaction table on gross return $\left(\mathrm{Rs} \mathrm{ha}^{-1}\right)$ of lentil as affected by irrigation and foliar spray of micronutrients and growth hormones

\begin{tabular}{|c|c|c|c|c|}
\hline $\mathbf{A} \times \mathbf{B}$ & $\mathbf{I}_{\mathbf{1}}$ & $\mathbf{I}_{\mathbf{2}}$ & Total & Mean \\
\hline $\mathbf{F}_{\mathbf{1}}$ & 29048 & 42207 & 71254 & 35627 \\
\hline $\mathbf{F}_{\mathbf{2}}$ & 40712 & 46138 & 86850 & 43425 \\
\hline $\mathbf{F}_{\mathbf{3}}$ & 48032 & 48232 & 96263 & 48132 \\
\hline $\mathbf{F}_{\mathbf{4}}$ & 42508 & 50261 & 92769 & 46385 \\
\hline $\mathbf{F}_{\mathbf{5}}$ & 44086 & 43548 & 87634 & 43817 \\
\hline $\mathbf{F}_{\mathbf{6}}$ & 46652 & 51661 & 98312 & 49156 \\
\hline $\mathbf{F}_{\mathbf{7}}$ & 48084 & 60414 & 108498 & 54249 \\
\hline Total & 299121 & 342460 & & \\
\hline Mean & 42732 & 48923 & & \\
\hline
\end{tabular}


Table.3 Interaction table on net return $\left(\mathrm{Rs} \mathrm{ha}^{-1}\right)$ of lentil as affected by irrigation and foliar spray of micronutrients and growth hormones

\begin{tabular}{|c|c|c|c|c|}
\hline $\mathbf{A} \times \mathbf{B}$ & $\mathbf{I}_{\mathbf{1}}$ & $\mathbf{I}_{\mathbf{2}}$ & Total & Mean \\
\hline $\mathbf{F}_{\mathbf{1}}$ & 12260 & 24919 & 37178 & 18589 \\
\hline $\mathbf{F}_{\mathbf{2}}$ & 22304 & 27230 & 49534 & 24767 \\
\hline $\mathbf{F}_{\mathbf{3}}$ & 30119 & 29819 & 59937 & 29969 \\
\hline $\mathbf{F}_{\mathbf{4}}$ & 24590 & 31843 & 56433 & 28217 \\
\hline $\mathbf{F}_{\mathbf{5}}$ & 25980 & 24942 & 50922 & 25461 \\
\hline $\mathbf{F}_{\mathbf{6}}$ & 27609 & 32118 & 59726 & 29863 \\
\hline $\mathbf{F}_{\mathbf{7}}$ & 27723 & 39553 & 67276 & 33638 \\
\hline Total & 170584 & 210423 & & \\
\hline Mean & 24369 & 30060 & & \\
\hline
\end{tabular}

Table.4 Interaction table on Return $\mathrm{Re}^{-1}$ Invested of lentil as affected by irrigation and foliar spray of micronutrients and growth hormones

\begin{tabular}{|c|c|c|c|c|}
\hline $\mathbf{A} \times \mathbf{B}$ & $\mathbf{I}_{\mathbf{1}}$ & $\mathbf{I}_{\mathbf{2}}$ & Total & Mean \\
\hline $\mathbf{F}_{\mathbf{1}}$ & 1.73 & 2.44 & 4.17 & 2.09 \\
\hline $\mathbf{F}_{\mathbf{2}}$ & 2.21 & 2.44 & 4.65 & 2.33 \\
\hline $\mathbf{F}_{\mathbf{3}}$ & 2.68 & 2.62 & 5.30 & 2.65 \\
\hline $\mathbf{F}_{\mathbf{4}}$ & 2.37 & 2.73 & 5.10 & 2.55 \\
\hline $\mathbf{F}_{\mathbf{5}}$ & 2.43 & 2.34 & 4.78 & 2.39 \\
\hline $\mathbf{F}_{\mathbf{6}}$ & 2.45 & 2.64 & 5.09 & 2.55 \\
\hline $\mathbf{F}_{\mathbf{7}}$ & 2.36 & 2.90 & 5.26 & 2.63 \\
\hline Total & 16.24 & 18.11 & & \\
\hline Mean & 2.32 & 2.59 & & \\
\hline
\end{tabular}


Table.5 Energetics of lentil as affected by irrigation levels and foliar spray of micronutrients and growth hormones

\begin{tabular}{|c|c|c|c|}
\hline \multicolumn{2}{|c|}{ Treatment } & \multirow{2}{*}{$\begin{array}{c}\text { Energy } \\
\text { output: input } \\
\text { ratio }\end{array}$} & \multirow[t]{2}{*}{$\begin{array}{l}\text { Energy use efficiency } \\
\left(\mathrm{kg} / \mathrm{MJ} \times 10^{-3}\right)\end{array}$} \\
\hline Irrig & levels & & \\
\hline $\mathbf{I}_{\mathbf{1}^{-}}$ & One irrigation (35 DAS) & 1.90 & 0.06 \\
\hline $\mathbf{I}_{2}-$ & Two irrigations (35 and 65 DAS) & 2.13 & 0.06 \\
\hline SEm & & 0.05 & 0.001 \\
\hline CD & & NS & 0.006 \\
\hline \multicolumn{4}{|c|}{ Foliar spray } \\
\hline $\mathbf{F}_{1^{-}}$ & Water Spray & 1.66 & 0.05 \\
\hline$F_{2^{-}}$ & Nitrobenzene@0.3\% & 1.84 & 0.06 \\
\hline $\mathbf{F}_{3-}$ & N:P: K:: 19:19:19@1\% & 2.13 & 0.06 \\
\hline $\mathbf{F}_{4-}$ & Multi Micro Nutrients (MMN) & 2.10 & 0.06 \\
\hline$F_{5^{-}}$ & $\begin{array}{l}\text { Plant Growth Hormones Mixture } \\
\text { (PGHM) @ 0.15\% }\end{array}$ & 1.94 & 0.06 \\
\hline$F_{6^{-}}$ & N: P: K:: 19:19:19: + MMN & 2.19 & 0.06 \\
\hline $\mathbf{F}_{7^{-}}$ & $\begin{array}{l}\text { N: P: K:: 19:19:19 + MMN + } \\
\text { PGHM }\end{array}$ & 2.22 & 0.06 \\
\hline \multicolumn{2}{|c|}{ SEm \pm} & 0.11 & 0.003 \\
\hline \multicolumn{2}{|c|}{$\mathrm{CD}(\mathrm{P}=\mathbf{0 . 0 5})$} & 0.34 & NS \\
\hline \multicolumn{2}{|c|}{ Interaction $\mathbf{I} \times \mathbf{F}$} & NS & NS \\
\hline
\end{tabular}

However, it was found at par to treatmentsF $6^{-}$ $\mathrm{N}: \mathrm{P}: \mathrm{K}::$ 19:19:19 + MMN (2.19) , $\mathrm{F}_{3}-\mathrm{N}: \mathrm{P}:$ $\mathrm{K}:: 19: 19: 19$ @ 1\% (2.13) and $\mathrm{F}_{4^{-}}$Multi micro nutrients (2.10). The minimum energy output: input ratio (1.66) was observed with F1- Control (water spray).

The differences in energy output: input ratio of lentil due to interaction effect of irrigation levels and foliar spray of micronutrients and growth hormones was found non- significant.

\section{Energy use efficiency $\left(\mathrm{kg} / \mathrm{MJ} \times 10^{-3}\right)$}

Data calculated on energy use efficiency of lentil at harvest have been presented in Table 5. Data shows that energy use efficiency was influenced by various irrigation levels.
Between the irrigation levels, energy use efficiency $\left(0.06 \mathrm{~kg} \quad \mathrm{MJ} \times 10^{-3} \mathrm{ha}^{-1}\right)$ was recorded significantly higher with $\mathrm{I}_{2}$-Two irrigations as compared to $\mathrm{I}_{1}$-One irrigation $\left(0.06 \mathrm{~kg} / \mathrm{MJ} \times 10^{-3}\right)$.

As regards to the foliar spray of micronutrients and growth hormones, none of the treatments gave significant effect on energy use efficiency.

The differences in energy use efficiency of lentil due to interaction effect of irrigation levels and foliar spray of micronutrients and growth hormones was found non- significant.

Sharma et al., (1998) and Gupta (2000) also observed similar findings. 
Conclusions of the study are as follows:

1. Due to production of more yield, net return and Return $\mathrm{Re}^{-1}$ invested were also recorded highest with irrigation level $\mathrm{I}_{2}-$ Two irrigations at 35 and 65DAS and foliar spray of $\mathrm{F}_{7}-\mathrm{N}$ : P: K:: 19:19:19 + $\mathrm{MMN}+$ PGHM followed by $\mathrm{F}_{3}-\mathrm{N}: \mathrm{P}: \mathrm{K}:$ : 19:19:19@1\%.Similarly, $\mathrm{F}_{4}$-Multi micro nutrients and $\mathrm{F}_{6}-\mathrm{N}: \mathrm{P}: \mathrm{K}::$ 19:19:19 + MMN also recorded comparable values of net return and return $\mathrm{Re}^{-1}$ invested.

2. Between the irrigation levels, nonsignificant effect was noted with regards to energy output: input ratio. As regards to foliar spray of micronutrients and growth hormones, treatment $\mathrm{F}_{7-} \mathrm{N}: \mathrm{P}: \mathrm{K}:$ : 19:19:19 + MMN + PGHM recorded significantly maximum energy output: input ratio. However, it was found at par to treatment $\mathrm{F}_{6}-\mathrm{N}: \mathrm{P}: \mathrm{K}::$ 19:19:19 + MMN, $F_{3}-\mathrm{N}: \mathrm{P}: \mathrm{K}::$ 19:19:19 @ 1\% and $\mathrm{F}_{4}$-Multi micro nutrients. The minimum energy output: input ratio was observed with $\mathrm{F}_{1}$ - Control (water spray).

3. Between the irrigation levels, energy use efficiency $\left(0.06 \mathrm{~kg} \quad / \mathrm{MJ} \times 10^{-3}\right)$ was recorded significantly higher with $\mathrm{I}_{2}$-Two irrigations as compared to $\mathrm{I}_{1}$-One irrigation $\left(0.06 \mathrm{~kg} \quad \mathrm{MJ} \times 10^{-3} \mathrm{ha}^{-1}\right)$. As regards to the foliar spray of micronutrients and growth hormones, none of the treatments gave significant effect on energy use efficiency.

\section{References}

Ashraf, M.Y., Baig, N.A. and Baig,F. 1989. Response of wheat (Triticum aestivum L.). Treated with cycocel under water stress conditions. Acta Agron. Hung., 38(3-4): 265-269.

Gupta, B. 2000. Efficacy of growth regulators on nodulation, flowering, pod setting and productivity of chickpea (Cicer arietinum L.) in Shrink Swell soils of Chhattisgarh plains. M.Sc. Ag. (Agronomy) Thesis, IGAU, Raipur.

Hernandez, P.1997. Morphogenesis in sunflower as affected by exogenous application of plant growth regulators. Agriscientia, 13:3-11.

Kumar,P., Vimal,S.C., Sarvjeet and Gupta, J.P.2017. Enhancement of yield components and seed quality parameters by growth regulator in lentil (Lens culinaris Medik.). N. D. University of Agriculture Technology, Kumarganj224229, Faizabad (U.P.) India. Journal of Pharmacognosy and Phytochemistry available online at www. phytojournal. com.

Sharma, H.O., Nahatkar, S.B. and Yadav, R.K. 1998. Production energy requirement of chickpea. Indian Journal of Pulses Research, 11 (2): 105-108.

Sitaram, T., Sharma, S. K. and Reager, M. L. 2013. Growth attributes and nutrient uptake of greengram as influenced by vermicompost and zinc in arid western Rajasthan. Advance Research Journal of Crop Improvement, 4 (1): 65-69.

\section{How to cite this article:}

Chandrakar, D.K., Bharti Sodi and Tarun. 2019. To Workout the Economics and Energetics of Lentil as Influenced by Irrigation and Foliar Spray of Nutrients and Growth Hormones. Int.J.Curr.Microbiol.App.Sci. 8(10): 1902-1908. doi: https://doi.org/10.20546/ijcmas.2019.810.221 